\title{
Venture Capital Financing for Innovative Start-up Companies in Nigeria
}

\author{
Article by Theophine U. Achugbu \\ Business and Management, Texila American University Guyana, South America. \\ E-mail: theoachugbu@gmail.com
}

\begin{abstract}
This study investigates the impact of venture capital (VC) financing on the growth of innovative start-up companies in Nigeria. The number of people that are extremely poor has fallen in all regions of the world except Sub-Saharan Africa. This has triggered a reinvigorated discourse, internationally, on the strategy to reduce poverty rate in the continent. Many African countries including Nigeria have taken bold steps towards crafting strategies to promote inclusive growth that incorporates private sector development. Supporting entrepreneurship by providing appropriate funding is one of the strategies. In developed countries, venture capital has significant impact on the performance of startups. In contrast, the performance of venture capital in developing countries especially Nigeria has been unsatisfactory. Venture capital industry in Nigeria is relatively nascent.

Exploratory research design was employed in this study due to the fact that venture capital is relatively an unknown area in Nigeria. This study adopted an inductive research approach. In addition, qualitative research method was employed. In-depth interviews were carried out to collect qualitative data and the data was subsequently analysed using content analysis method. A sample of 30 start-ups from a total population of 120 start-ups in Onitsha, Awka, Nnewi and Abuja was randomly drawn using systematic sampling technique. Qualitative data analysis was performed using NVivo which is a comprehensive qualitative data analysis software package. NVivo software was used to organize and analyse in-depth interviews, field notes and textual sources.

It was found that venture capital financing has an impact on the growth of innovative start-ups. The use of VC financing increased profitability, spurs employment growth, boosted asset base, and improved the quality of management for VC-backed start-ups. Taking into account this positive trend in enterprise sustainability, it was concluded from the study that Venture capital-backed start-ups will make more meaningful contributions to the society. These contributions could be in form of improvement in productivity, reduction in poverty rate, paying taxes to government and overall growth of the economy. The recommendation from the study was that there should be an enabling environment for $V C$ investments to blossom.
\end{abstract}

Keywords: Venture capital finance, start-up companies, entrepreneurship, innovation.

\section{Introduction}

In recent years, more attention has been paid to poverty reduction in the world especially in developing countries. Despite the fact that the non-monetary dimensions of poverty in Africa have been progressively improving, today, more people according to World Bank are poor than in 1990 (as cited in Caulderwood, 2015). The World Bank report found that the number of people that are extremely poor has fallen in all regions of the world except sub-Saharan Africa. The report attributed this lack of progress in the region to the astronomical rise in population growth which exceeds the rate of poverty reduction.

In an effort towards eradicating extreme poverty (especially in Sub-Saharan Africa) which is in line with the Sustainable Development Goal no.1, many African countries have come up with new strategies to promote inclusive growth. According to UNDP (2012) report, a non-inclusive growth has negative effects not only on the economy but also the society at large and leads to inequalities which subsequently result in negative social outcomes. Similarly, the report indicated that inclusive growth fosters economic growth by expanding the foundation for domestic demand and at same time widening opportunities for greater participation by young, small enterprises in the economy. The report further highlighted that private sector plays a very important role in promoting inclusive 
markets and this role is highly essential both socially and economically since it's the responsibility of the private sector to extend economic opportunities to young \& innovative small enterprises.

Private sector development varies widely throughout Africa and depends on the country. Small enterprises are prospering in Mauritius, South Africa and North Africa due mainly to the fairly developed financial systems and appropriate government policies that favour private enterprise (Kauffmann, 2005). In some other countries of Africa, the development of small businesses according to Kauffmann has been impeded by political instability on the one hand and over reliance on a few raw materials on the other hand. Small enterprises in Nigeria which contribute roughly 95 percent of established manufacturing activity are essential to the economy but corruption, poor infrastructure and insecurity inhibit the enterprises from being engines of growth (Kauffmann, 2005).

The Nigerian government established Small and Medium Enterprises Equity Investment Scheme (SMEEIS) in 2001though it was approved by the Bankers' Committee at its $246^{\text {th }}$ meeting held in December 1999 (Central Bank of Nigeria, 2005). Under the scheme, all banks in Nigeria were required to set apart and appropriate 10 percent of their profit after tax (PAT) for equity investment and also to boost young, small and innovative start-up companies. To maintain a progressive balance in a real economy, Ollor \& Dagogo (2009) stress that the real sector and financial sector must complement each other, thus any defect in one sector hinders developments in the other. Nevertheless, in Nigeria, evidence indicates that both sectors are nearly divorced with minimal symbiotic relationship such that the financial sector milk-dries the real sector (Soludo, 2004 and Sanusi, 2003). Though start-ups contribute immensely to economic growth, it is regrettable that many creative individuals incubate new \& imaginative ideas that don't hatch ultimately due to lack of finance. Owing to diminishing availability of the traditional sources of capital such as traditional bank loans, there is a need to introduce clients (like new enterprises) to some of the new and dynamic trends that are recently taking place in start-up financing (Goldberg, 2012). While Goldberg recognizes some of the relatively new sources of financing for start-ups such as venture capital, business angels and corporate venture capital, he particularly highlights the increasing popularity of crowdfunding as a new paradigm in start-up financing. It is worthy of mention that this study will focus on venture capital as a major source of finance for start-ups.

Venture capital industry in Nigeria is relatively nascent though there has been much interest recently in the concept of venture capital and its relevance in the Nigerian society. Venture Capital in Nigeria has been underdeveloped even as an investment hub of Africa (Daramola, 2012). Prior to 1997, the Venture Capital incentives Act, according to Daramola (2012) saw the creation of the National Risk Fund Plc in 1987 and this became the country's first Venture Capital Company. In 2001, the activities of Venture Capital in Nigeria were complemented with the establishment of 'The Small \& Medium-Scale Enterprises Equity Investment Scheme' (SMEEIS) to promote start-ups and SMEs through equity-based financing rather than debt financing. This paradigm shift in financing structure was widely commended and seen as a solution to the entrepreneurial quandary in Nigeria. Essentially, the SMEEIS scheme entails using Venture Capital (VC) to support entrepreneurship ventures. Venture capital financing in Nigeria is critical to the growth and development of the economy because it boosts job creation hence reducing the current high unemployment rate in the country (Daramola, 2012).

Literature suggests that start-up companies all over the world face many obstacles to funding. In Nigeria, these obstacles are compounded by the undeveloped venture capital industry. The private sector has been neglected for so long by successive governments in Nigeria. As the private sector is the pillar of every economy, this study will extensively unmask and bring to bear barriers to start-ups and small businesses' VC funding.

\section{Significance of the study}

Employment and productivity are key issues that are pivotal to economic and social life of all nations (Obadan \& Odusola, 2000). Unemployment has been categorized as a major obstacle to social and economic progress and represents a colossal waste of a nation's manpower resources, causes lower output leading to lower income and prosperity and subsequently diminishes welfare of citizens 
(Akinboyo, 1987; and Raheem, 1993). Unemployment is not only a cost to a country but a serious macroeconomic issue that needs urgent attention in the continent of Africa particularly Nigeria. The Nigerian contemporary society has been heavily overwhelmed by uncontrolled vices like terrorism, drug trafficking, prostitution, hostage taking, armed robbery, militancy, to mention but a few hence negatively affecting the foundation and values upheld by its citizens. Many experts and non-experts in the development discourse argue that the reasons for these vices are not far-fetched and they attributed the menace to high rate of unemployment in the country.

Moreover, there has been an overreliance on oil revenue by successive Nigerian governments since independence thereby neglecting or failing to leverage the enormous resources from other sectors of the economy. This overreliance on oil comes with a cost in terms of vagaries in crude oil price in the international market which may result to decline in revenue thus impacting on capital expenditure and the provision of necessary infrastructures to the citizens. According to Central Bank of Nigeria (2016), the dwindling revenue from oil which has persisted for a while is attributed to the continuous drop in the crude oil price in the international market. The apex bank further emphasizes that other reasons like the shut-downs at some Nigerian National Petroleum Corporation's (NNPC) terminals due to vandalization of pipelines in the Niger Delta region are also blamed for this fall.

There is an urgent need to reduce the cost of unemployment by the Nigerian government through the promotion of start-ups and small enterprises. To achieve this, this study will provide the government and other relevant stakeholders with the needed information for policy making in the area of encouraging institutional investors capable of pooling venture capital funds. In line with the above, Cumming et al (2008) stress that Banks along with other institutional investors play vital roles in the transformation of savings into investments thus helping in the facilitation of liquidity, consumption smoothing and information. Institutional investors include banks, pension funds, life insurance companies etc which can collaborate in form of limited partners and making contributions and pooling funds known as the venture capital funds.

\section{Statement of the problem}

A large number of start-ups and small enterprises wallow in stagnation and eventual collapse due to dearth of funds for growth and expansion. Start-ups that lack funds for growth will neither create jobs nor make any contribution to economic/social development and to Gross Domestic Product (GDP) of a country (White Paper on International Development, 2000). Randall Kempner observes that startups and small-sized companies in Africa are few and notes that most countries in the Sub-Saharan Africa are trapped in a narrow formal economy, yet these companies are the pillars of economic growth (as cited in AVCA, 2015). Start-ups and small enterprises play a vital role in the society especially as they not only fill the "missing-middle" but subsequently metamorphose into mediumsized companies of tomorrow. The main challenge for Africa's sustainable and inclusive growth according to Randall Kempner is the identification of these job-creating start-ups and providing them with the needed finance and insights. Though there have been emphases on the heightened support for start-ups in Africa, however there are still financing gaps for these early-stage small enterprises. In Nigeria for example, the gaps inhibit the growth of start-up companies which apparently diminish the overall economic growth of the country. To bridge or reduce these gaps, the boundaries of the gaps need to be established and ascertained (AVCA, 2015).

Similarly, Hallberg (1998) \& Mead \& Liedholm (1998) found that an essential ingredient to the development of start-ups and small enterprises is access to finance. Start-up companies do not have many alternatives to access to finance and many of them rely mostly on their personal savings for the growth of their ventures. In entrepreneurship, financing gap has been historically a major impediment in the growth of young enterprises. It's worth mentioning that the history and the word "Venture Capital ee emanated from a discussion between J.H Whitney and Benno Schmidt where Whitney had set up an investment development fund to fill in the financing gap of those who could not access capital from banks and lending institutions (Cornelius 2005, p.599). However, access to finance for start-up companies in Nigeria has been exacerbated by the under developed VC industry and the unattainable collateral imposed on entrepreneurs. A huge fraction of lenders impose unattainable 
collateral and servicing requirements which according to Waddell (1995) are clearly beyond the bounds of possibility for new innovative start-ups and expanding businesses.

Relatedly, Mani \& Bartzokas (2004) state that small and young businesses in their early stages of growth cycle lack the needed assets, repayment history or proof of profitability that will suffice as collateral for loans from banks. As a result, they reiterate that venture capital can fill this gap by playing a vital role of establishing knowledge as information producers who in turn make detailed assessment of the investment plans. Also in contrast to Banks and other lenders, venture capitalists supply funds to new enterprises without these prerequisites but metamorphose into part owners of a new enterprise with the equity investment customarily for 7 to 10 years. The information challenges will then be ameliorated by detailed screening, contracting \& monitoring of investment by the VC. While highlighting the importance of venture capital to business formation and expansion, Waddell (1995) stress that venture capital is difficult to obtain. In a study in Ghana by Poku \& Frimpong (2009) on the evaluation of how start-ups and small enterprises perceive the prospects and capability of venture capital financing to bridge the financing gaps facing small enterprises in Ghana, they came up with some interesting findings. The study found that, firstly, there is general reluctance by entrepreneurs in seeking VC financing in order to avoid dilution of control; secondly, there is concentration of VC operations in urban areas; and thirdly, VC investment is mainly for few sectors of the economy hence lacking the needed spread.

Earlier study on 'The Growth and prospect for Venture Capital activities in Nigeria' by Ariyo (2000) only focused on the generic prospects of venture capital in Nigeria. The study did not underscore the funding gaps between VCs and start-up companies. The research by Ollor \& Dagogo (2009) on 'The Effect of Venture Capital Financing on the Economic Value Added Profile of Nigerian SMEs' concentrated on comparing the economic value added of venture capital-backed SMEs and those of non-venture capital-backed SMEs. Their findings indicated that VC- financed SMEs clearly outperformed non-VC-financed SMEs. Though this study has a connection with few earlier researches, venture capital financing for innovative start-up companies in Nigeria has not been carried out. Nevertheless, there are a handful of innovative start-ups that have benefitted from VC financing in Nigeria. I contend that despite the fact that Venture Capital Companies have been operating in Nigeria as early as 1987, there are still few critical financing gaps that need to be closed such as: (a) Lack of general knowledge of sources of risk capital and also insufficient comprehension of the operational and financial requirements of $\mathrm{VC}$ on the part of entrepreneurs; (b) there is concentration of VC operations in very few urban areas in Nigeria thus making it difficult for startups in other parts of the country to have smooth access to VCs.

\section{Objective of the study}

The general objective of this study was to determine the impact of Venture Capital financing on innovative start-up companies in Nigeria.

\section{Specific objectives}

1. To examine the challenges faced by start-ups in raising venture capital finance

2. To investigate if venture capital finance leads to growth of start-up companies

3. To establish the impact of venture capital on management style used by start-up companies.

4. To explore the recent trends in VC financing in Nigeria in the areas of distribution of investments across sectors.

5. To explore the preferred sources of finance used by start-up companies

6. To examine other challenges faced by entrepreneurs in the process of obtaining capital for their start-up companies

\section{Research questions}

a) What are the challenges faced by start-ups in the process of attracting and obtaining venture capital finance?

b) Does venture capital finance lead to growth of start-ups and small enterprises?

c) What's the impact of venture capital on the management style applied by start-up companies? 
d) What are the recent trends in venture capital financing activities in Nigeria in terms of the distribution of investments across industries?

e) What are the preferred sources of finance used by start-up companies in Nigeria?

f) What other challenges impede the access of start-ups to finance for growth?

\section{Literature review}

\section{Innovation and its relevance}

Urgent developmental challenges such as reducing hunger, eradicating neglected diseases and providing access to drinking water can be tackled by innovation. In achieving these goals, the transfer and, when required, adaptation of necessary technologies developed in industrialized countries can make significant contributions (OECD 2012). While sizeable research efforts are required to find solutions that address other challenges globally, a fruitful international cooperation involving both private and public bodies will serve as significant mechanism in finding these solutions. In highlighting the significant role played by innovation in the past two decades, OECD (2012) found that the build-up of innovation capacities has played a pivotal role in the growth dynamics of successful developing nations. These successful countries have come to the realization that innovation is more than just developing high-technology products. The countries have also acknowledged that innovation capacity has to be enshrined in the early part of the development process in order to acquire capacities for learning that will eventually permit "catch-up" to happen. The OECD paper equally revealed that these successful developing nations needed to sort out their specific local challenges such as tropical diseases through local innovations and innovation capacity. Despite the fact that innovation is significant in all stages of development, different types of innovation play divergent roles at various stages (OECD 2012). In the early stages of development, innovation is incremental and is often linked with the adoption of foreign technology. High technology R\&D-based innovation is often brought to bear \& matters at later stages of development when the two factors of competitiveness and of learning play up (which allows for the completion of the "catch-up" process).

In his initial claim, Joseph Schumpeter asserts that dynamic entrepreneurs remain the source of innovation though his later works ascribed and associated innovation to large corporations (as cited in Geronikolaou \& Papachristou, 2012). Big firms have an advantage over smaller firms due to imperfections in capital market and information asymmetries and their capability to provide funding for independent $\mathrm{R} \& \mathrm{D}$ projects using their own resources. A lot of recent studies investigating the correlation between firm's size and production of innovation appear to be inconclusive (Tether, 1998). Nevertheless, the evolution of venture capital markets in contemporary economies has injected some support to the initial claim of Joseph Schumpeter. As a result of the dearth of collateral, small and innovative start-up companies, predominantly individual entrepreneurs have very limited access to capital markets for financing their ventures \& projects. As an alternative, Geronikolaou \&Papachristou (2012) stress that external equity in the form of venture capital can effectively bridge this funding gap. Venture Capital (VC) fund managers thus provide equity to small, dynamic and innovative start-up companies and hence become co-owners of the investee's project.

\section{Significance of entrepreneurship development in nigeria}

The accomplishment and effectiveness of entrepreneurship in Nigeria towards boosting economic growth, considering the enormous human and natural resources in the country have been under close examination by economic experts and other stakeholders. This intense examination is attributable to the dismal performance and contribution of entrepreneurship as a catalyst for economic growth and development. Despite the huge resources in the country, Anyadike, Emeh and Ukah (2012) maintain that Nigeria is still ranked as one of the poorest countries globally and equally has one of the highest rates of youth unemployment in comparison with other sub-Saharan African countries. They emphasize that unemployment rate in the country is still at all-time high despite the recent purported positive economic outlook and growth. They further reiterate that successive governments in Nigeria have been insensitive to the frustrations and predicaments of the citizens and as a result increasing the rate of crime and other vices in the country. Though Ovat (2013) agrees that a country's human and 
material resources to a reasonable extent spur economic growth, he however emphasizes that the economic development can only be achieved with a proper organisation and coordination of these resources into productive use via an entrepreneur. According to Ihugba, Odii \& Njoku, (2013), entrepreneurship development is vital for a country's prosperity because it helps in eradicating extreme hunger and poverty caused by unemployment. The importance of entrepreneurship development in Nigeria according to Ovat (2013) cannot be overstressed and argues that it would achieve the following: job creation; enhancement in living standards; minimizing hopelessness \& tension among the youths; poverty reduction/eradication \& wealth creation; capital formation in form of net capital accumulation; balance development in the regions; achievement of economic independence; achievement of desired innovation for sustainable development; promote development in all spheres of the economy and encourage inward investment.

\section{Start-ups and economic growth}

Recent literature indicates that there are two types of competition that may contribute to macroeconomic performance: firstly, the magnitude of new-firm entry and secondly, the degree of competition among incumbent firms (Koster \& Stel, 2014).They referred to the employment growth using the start-up rate as capturing the direct effect of new company formation, while the competition among incumbents (market mobility) as capturing the indirect effect. Additionally, they found that the long-term economic effect of start-up companies is larger than the short-term effect. They further supported their finding empirically by asserting that the most successful start-up companies develop to become high- growth companies and also the entry of new companies galvanize incumbent companies to perform better.

Relatedly, Fritsch and Noseleit, (2009) maintain that though new companies have a direct impact in form of creating employment for workers, the more significant impact is presumed to be indirect by stimulating incumbent companies to strive for better performance. Results of a study by Fritsch (2008) suggest that new companies on entering the market, induce competition among incumbent companies (i.e. market mobility) thus leading to economic growth. This involves fierce competition when these new companies enter the market with new products \& services, consequently challenging incumbent companies to make improvements in their performance. An important finding from the research by Acs and Storey (2004), Fritsch (2008) and Dejardin and Fritsch (2011) revealed that startup companies have immediate or direct effect on employment growth. They note that in terms of employment, the immediate or direct effect is in form of the additional labour required in the newly established companies. Likewise, Wennekers \& Thurik (1999), Carree \& Thurik (2003) and Fritsch \& Mueller (2004) contend that start-ups effects on firm level can be differentiated into direct effects and indirect supply side effects (intermediate linkages). As noted by them, direct effects include new employment and new production created by the start-ups and also direct contributions by the start-ups to in-migration and heightened regional productivity. Westlund \& Olsson (2011) note that direct effects equally comprise of closure or decline of incumbents that might not be able to face the new competition. Additionally, the indirect supply side effects as stressed by Fritsch \& Mueller (2004) are segregated into four parts. First, Start-ups coerce incumbents to behave more efficiently (secured efficiency); second, there is substitution of incumbents by new firms (acceleration of structural change); third, new companies may initiate innovations (amplified innovation); and fourth, new companies may lead to substantial product variety and problem solutions (greater variety).

\section{The influence of VC financing on innovative start-ups}

Existing literature indicates that there is remarkable difference between start-ups using venture capital and start-ups utilizing more traditional alternatives of financing (Hellman \& Puri, 1999a). They found that start-ups using venture capital follow strategies that are more innovative and take shorter time to introduce their products and services to the market. Finding from previous research also suggests that the presence of venture capital affects the advent of human resource practices in start-up companies (Baron et al., 1996). In highlighting certain characteristics that set venture capital apart from more traditional sources or debt financing alternatives, Gompers and Lerner (1999) argue 
that venture capital companies channel sufficient management resources to comprehending new technologies and markets. Additionally, the use of these resources helps in discovering promising start-ups and providing them with both financial resources and coaching that are necessary to nurture them through the early part of their lives. The contributions of managerial resources to the growth path of recently formed start-ups are important to management theory (Gimeno et al., 1997).

In the same vein, Penrose (1959) underscores the vital role played by managerial resources in his original study, "theory of the growth of the firm". There exist numerous rationales for expecting startups backed by venture capital companies to have higher than average rate of growth. Venture capitalists customarily augment the skill set of the existing management team of the young start-up in a far more proactive manner than other financing methods like bank loans (Davila et al., 2003). From a governance point of view, venture capitalists take an active board role in structuring not only top managers' compensation but also monitoring periodically the evolution of the start-up firm (Kaplan and Stromberg, 2003). They also bring huge network of contacts with knowledgeable and skilful infrastructure providers (such as law firms, public relations firms, and accounting firms) and potential masterly and experienced managers. The contacts according to Pfeffer \& Salancik smooth access to external resources that mitigate the resource dependencies that are experienced by start-ups (as cited in Davila et al., 2003). Venture capitalists usher in reputation effect to investee companies and significantly, the successful passing of a venture capitalist screening and subsequently receiving funding (usually in multiple rounds) is a strong signal to numerous parties and stakeholders both inside and outside the start-up. With this reputation endowed to start-ups, uncertainty not only reduces but also transaction costs diminish. This combined advantage of skill augmentation and reputation boost according to Davila et al. (2003) can result in venture-backed start-ups having a huge benefit in gaining new customers, attracting high quality employees and negotiating alliances and joint ventures with key players. However, Davila et al., (2003) argue that attracting the attention of venture capital companies still remains a difficult activity. They emphasize that cash flow glitches within a start-up company can result in freezes in hiring employees until a new round of financing is sealed. Potential employees may be reluctant to commit to start-up that has not obtained its latest round of financing. As a result of a new round of financing, positive signals may be sent to potential employees who are more inclined to accept the offer once they see that the start-up has been funded by venture capitalist.

\section{Methodology}

Exploratory research design was employed in this study. Depending on the research purpose, projects carried out under scientific research can be categorized into three types, namely: exploratory, descriptive and explanatory. Exploratory research is commonly carried out in new areas of inquiry, where the research goals are: (a) to examine the extent or magnitude of a particular phenomenon, behaviour or problem, (b) to create or produce some initial ideas about that phenomenon, and (c) to check how feasible it is to undertake a more extensive study with regard to that phenomenon (Bhattacherjee, A. 2012). Exploratory research is carried out into a problem or an issue where there is small number or no earlier studies to make reference to (Newman, 1994). Kothari (2003) affirms that exploratory research design is flexible and permits the researcher to take into consideration numerous divergent facets of a problem thus assisting the researcher to gain fresh insights about the problem.

This study adopted an inductive research approach. Despite the fact that there has been much interest recently in the concept of venture capital in Nigeria, the industry is relatively developing hence the choice of inductive research approach. Bhattacherjee, A. (2012) emphasises that though deductive and inductive research are significant for the promotion of science, inductive (theorybuilding) research is more valuable when there are few prior theories.

For this study, the population consisted of all start-ups in Onitsha, Awka, Nnewi and Abuja totalling 120. This figure was arrived at by accessing reputable online start-up directories in Nigeria. Due to time and financial constraints, I could not practically collect data for all start-ups in Nigeria thus the definition of specific population from few major cities in Nigeria.

The study adopted qualitative approach using in depth interview method where 30 start-ups (from a population of 120) were selected for the in depth interviews (see table 1). Sampling frame was drawn 
from start-up directories in Nigeria such as startupranking.com-with web analytics; Angellist directory; Smileandmobile.com; Techcrunch.com; Techpoint.ng; Nigeia.startups-list.com. There is a frequently asked question by students conducting qualitative research on 'how many interviews is enough?' Baker and Edwards (2016) collected some responses (drawing on the tacit knowledge) from 14 renowned social scientists and seasoned methodologists in order to proffer answers to this question. Majority of the contributors believe that 'it depends' or that 'it is a function' of some factors such as methodological, epistemological and practical issues.

Table 1. Sample size

\begin{tabular}{|l|l|}
\hline Cities & Number of startups \\
\hline Onitsha & 4 \\
\hline Awka & 3 \\
\hline Nnewi & 2 \\
\hline Abuja & 21 \\
\hline Total sample size & 30 \\
\hline
\end{tabular}

Systematic sampling technique (a subset of probability sampling) was utilized to determine the sample size. Generally, Henry (1990) contends that making use of sampling creates the possibility of a higher overall accuracy than a census. He emphasizes that when data is collected on a small number of cases there will be more time to spend in designing and piloting the means of collecting these data. Systematic sampling technique as pointed by Sekaran (2003) is a process where every nth element from the population is drawn beginning with a randomly selected element between 1 and $n$.

Making sense of large amounts of data throughout data collection and analysis process poses a huge challenge to researchers. These challenges also include reducing the volume of information, identifying important patterns and subsequently constructing a framework from the data (Merriam, 1998). In this study, qualitative data analysis was performed using NVivo which is a comprehensive qualitative data analysis software package. I used NVivo software to organize and analyse in-depth interviews, field notes, textual sources and video files. The coded interview transcripts were imported in $\operatorname{doc}(\mathrm{x})$ and .pdf documents to NVivo software for analysis. To make more sense of the enormous pool of data, I intuitively view the whole process of data analysis from three angles: (a) I compared threads and patterns within identified categories; (b) Comparisons between connecting threads and patterns across identified categories were made, and (c) Although prior research on VC in Nigeria isn't broad, and also noting that this study was situated with reference to previous research, I compared the issues on the study with those raised by broader literature. Considering the broader implications of this study, conclusions and recommendations were formulated.

\section{Data analysis}

\section{Location of business}

Intriguingly, out of 30 start-ups selected for this study, 4 were located in Onitsha, 3 were located in Awka, 2 were located in Nnewi while 21 were located in Abuja the capital of Nigeria. Table 2 illustrates sector distribution in the four locations. Out of 4 start-ups located in Onitsha, 1 was in ICT sector, 1 in manufacturing sector and 2 in education sector. In Awka, all the 3 start-ups were in ICT sector. In a similar vein, there was 1 start-up in financial services sector and 1 in ICT sector making up the total of 2 start-ups located in Nnewi. Out of 21 start-ups located in Abuja, 3 were in financial services sector, 9 in ICT sector, 2 in agricultural sector, 1 in oil \& gas, 1 in healthcare, 3 in education, 1 in merchandizing and 1 in property sector. This makes Abuja the highest in terms of location of start-ups with a staggering 21 start-ups out of 30 . Results of the study also indicates that in terms of frequency distribution of sectors in the 4 locations, ICT was the most widely spread and cuts across the 4 locations with 14 start-ups out of 30. Education sector occupied a distant second position in terms of spread with 5 start-ups while the remaining 7 sectors had 4 or less. 
Table 2. Table for location of business

\begin{tabular}{|c|c|c|c|c|c|c|c|c|c|c|}
\hline & & & & $\begin{array}{l}\text { Type of } \\
\text { Business }\end{array}$ & & & & & & \\
\hline Location & $\begin{array}{l}\text { Financial } \\
\text { Services }\end{array}$ & ICT & Agriculture & MfG & $\begin{array}{l}\text { Oil \& } \\
\text { Gas }\end{array}$ & Healthcare & Education & Mdsg & Property & Total \\
\hline Onitsha & 0 & 1 & 0 & 1 & 0 & 0 & 2 & 0 & 0 & 4 \\
\hline Awka & 0 & 3 & 0 & 0 & 0 & 0 & 0 & 0 & 0 & 3 \\
\hline Nnewi & 1 & 1 & 0 & 0 & 0 & 0 & 0 & 0 & 0 & 2 \\
\hline Abuja & 3 & 9 & 2 & 0 & 1 & 1 & 3 & 1 & 1 & 21 \\
\hline Total & 4 & 14 & 2 & 1 & 1 & 1 & 5 & 1 & 1 & 30 \\
\hline
\end{tabular}

MfG= Manufacturing

Mdsg $=$ Merchandising 


\section{Sector spread (Type of business)}

The study (as shown in figure 1) revealed that 14 entrepreneurs out of 30 (47\%) established ICTfocused enterprises. Education related start-ups had 17\%, financial services $13 \%$, agriculture $8 \%$, manufacturing $3 \%$, oil \& gas $3 \%$, healthcare $3 \%$, merchandizing $3 \%$ and property $3 \%$. The findings indicate that many start-up companies focus on Information and Communications Technology (ICT) sector. Literature suggests that this preference for ICT industry is a combination of many factors. Prahalad \& Hammond (2002) emphasise that ICT is not only central to economic innovation but a powerful tool for development especially in developing countries.

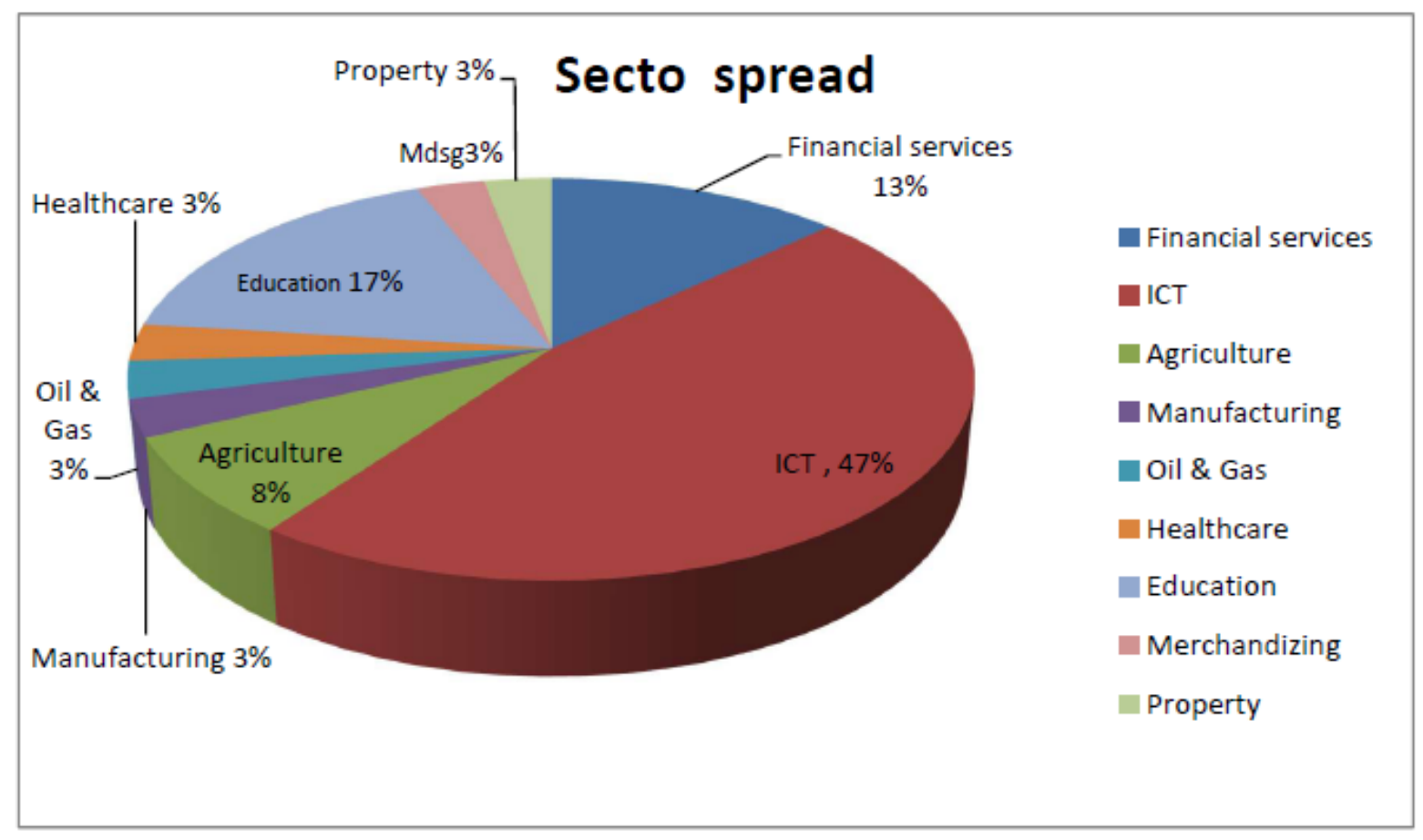

Figure 1. Sector spread (type of business).

\section{Number of employees}

Research findings revealed that the minimum number of employees in individual start-up companies was 4 while the maximum number was 22 as illustrated in Table 3 . The study equally indicated that out of 30 start-up companies, only 6 start-ups employed between 16 and 22 employees which were above the mean value. These companies were: INNV, AJMAR, JBMA, STEC, NPTC and HTNIG. It is worthy of mention that these 6 companies were the only start-up companies out 30 that have obtained VC finance as showed in figure 4 below. The study also showed that $43 \%$ of the total number of employees at the 30 start-up companies was employed by just 6 companies that obtained $\mathrm{VC}$ finance.

Table 3. Number of employees employed by individual start-ups

\begin{tabular}{llllll}
\hline $\begin{array}{l}\text { Number } \\
\text { of start- } \\
\text { ups }\end{array}$ & $\begin{array}{l}\text { Total } \\
\text { number of } \\
\text { employees }\end{array}$ & $\begin{array}{l}\text { Min. No. } \\
\text { Of } \\
\text { employees }\end{array}$ & $\begin{array}{l}\text { Max. No. } \\
\text { Of } \\
\text { employees }\end{array}$ & Mean & $\begin{array}{l}\text { Std. } \\
\text { Deviation }\end{array}$ \\
\hline & & & & & \\
30 & 266 & 4 & 22 & 9 & 9 \\
\hline
\end{tabular}


Table 4. Six start-up companies that obtained VC finance

\begin{tabular}{lll}
$\begin{array}{l}\text { Total number of } \\
\text { start-ups }\end{array}$ & $\begin{array}{l}\text { Start-ups that obtained } \\
\text { VC }\end{array}$ & $\begin{array}{l}\text { No. Of } \\
\text { employees }\end{array}$ \\
\hline & & \\
& INNV & 16 \\
& AJMAR & 22 \\
& JBMA & 18 \\
& STEC & 20 \\
& NPTC & 18 \\
& HTNIG & 21 \\
& & \\
\hline Total 30 & 6 & 115 \\
\hline
\end{tabular}

\section{The relationships between research themes/categories/nodes and research objectives}

To better comprehend the phenomenon that exists about the research topic, 'Venture Capital financing for innovative start-up companies in Nigeria', from the hundreds of pages of transcripts, the data was transcribed into a more meaningful form. A critical examination and careful interpretation of data was done resulting to the identification of patterns, meaningful categories, coherent themes and new ideas. The major themes and patterns discovered were: dearth of information about VC operations, lack of knowledge, not many business angels, few venture capitalists \& few VC-backable ventures, proximity to VC firms, banking facilities, poverty level, reliance on personal savings \& friends \& family, dilution of control, issue of trust \& rigorous process, capital market, macro level uncertainty, emerging industry, regulatory environment, management style, stringent collateral requirements, no real VC presence and economic environment. The themes were also presented in figure 2 below.

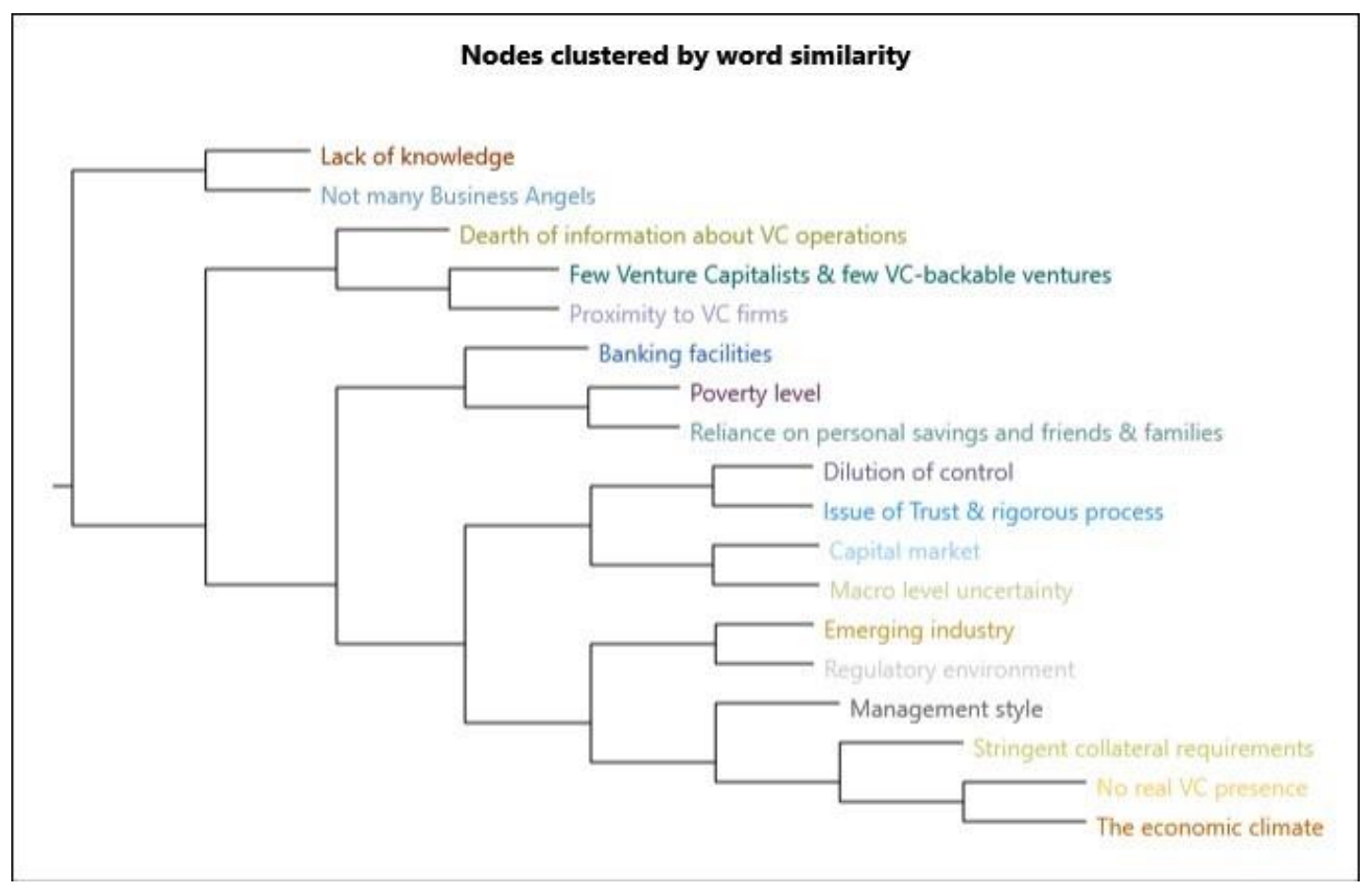

Figure 2. Themes and patterns

\section{The influence of venture capital finance on the growth of start-ups}

Table 5 indicates that 6 out of 30 start-ups obtained VC capital. It shows that the total number of employees for the whole 6 companies before they obtained VC finance was 31 while the total number 
of employees after availing of $\mathrm{VC}$ finance was 115 . The percentage increase in the number of employees for the 6 companies after obtaining VC was between 200\%-350\%.

Table 5. Number of employees before and after venture capital

\begin{tabular}{lllll}
\hline $\begin{array}{l}\text { No. Of } \\
\text { startups that } \\
\text { obtained VC }\end{array}$ & $\begin{array}{l}\text { No. Of employees } \\
\text { before VC }\end{array}$ & $\begin{array}{l}\text { No. Of } \\
\text { employees after } \\
\text { VC }\end{array}$ & $\begin{array}{l}\text { \% } \\
\text { Change }\end{array}$ \\
\hline & & & \\
INNV & 4 & 16 & 300 \\
AJMAR & 6 & 22 & 267 \\
& JBMA & 5 & 18 & 260 \\
& STEC & 5 & 20 & 300 \\
& NPTC & 4 & 18 & 350 \\
& HTNIG & 7 & 21 & 200 \\
\hline Total & 6 & 31 & & \\
\hline
\end{tabular}

The study also revealed, as shown in figure 3 that $66 \%$ of the participants stated that profit before the use of venture capital was poor while $17 \%$ reported that profit was good and the remaining $17 \%$ expressed that profit was fair.

\section{Parti ipants' comments on profitability before venture capital}

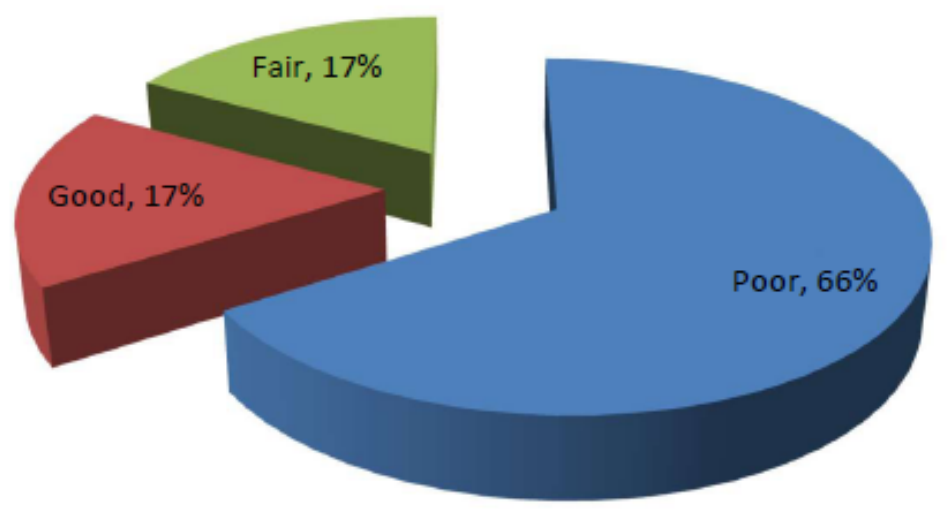

Figure 3. Comments on profitability before venture capital

\section{Summary, Conclusion and recommendations}

\section{Summary}

What are the challenges faced by start-ups in the process of attracting and obtaining venture capital finance?

The findings revealed that start-up companies in Nigeria face enormous challenges in raising venture capital finance. These challenges are: macro level uncertainty, Dearth of information about VC operations, Few Venture capitalists \& few VC-backable ventures, Issues of trust and rigorous process, Dilution of control, Lack of knowledge of sources of finance, Proximity to VC firms and No 
real VC presence. In each of the challenges, more than 50\% of the participants expressed deep concern about the financing gap created as a result.

\section{Does venture capital financing lead to growth of start-ups and small enterprises?}

All the start-up companies that obtained venture capital finance recorded astronomical increase in the number of employees in their first year of operation. These VC-backed start-ups achieved between $200 \%-350 \%$ annual increase in the number of employees. In terms of profitability of the start-up companies, $66 \%$ of VC-backed start-ups affirmed that profitability was very poor before obtaining venture capital finance. The finding revealed that after obtaining venture capital finance, $83 \%$ of startups that utilized $\mathrm{VC}$ expressed that profit surged. A significant finding here was that start-up companies achieved an impressive growth in the number of employees and overall profitability after obtaining venture capital finance.

\section{What's the impact of venture capital on the management style applied by start-up companies?}

Findings indicate that management of start-up companies was very uncomfortable with employee involvement before utilizing venture capital finance especially in the decision making process. There was a remarkable improvement in the relationship between management and employees after obtaining venture capital. The study showed that management (of all VC-backed start-ups) adopted a more democratic style of leadership where effective collaboration between management and employees became the norm. Finding in this study also revealed that there was a splendid improvement in the communication flow between employees and management and management regularly meet with employees before taking final decision on crucial issues.

What are the recent trends in venture capital financing activities in Nigeria in terms of the distribution of investments across industries?

Venture capital investment in Nigeria favoured technology sector more than any other sector. In spite of the fact that $\mathrm{VC}$ investment in some sectors might be static, findings show that there was a heightened $\mathrm{VC}$ investment in technology sector.

\section{What are the preferred sources of finance used by start-up companies in Nigeria?}

Most start-ups pointed out that they prefer raising the initial capital through friends \& family and their personal savings. This preference was as a result of the ease and inexpensiveness of the method in comparison with other sources of funding. Significantly, the study revealed that an overwhelming majority of start-ups rely on personal savings and friends \& family members to finance their ventures.

\section{What other challenges impede the access of start-ups to finance for growth?}

The study exposed vastly other obstacles faced by start-ups in accessing finance for growth. Findings revealed that other challenges encountered by start-ups in raising finance in Nigeria include: venture capital is in its embryonic stage; undeveloped capital market; stringent collateral requirements; few business angels; poverty level; Banks' reluctance to extend banking facilities to start-ups and regulatory environment.

\section{Conclusion}

The present study reveals that the impact of venture capital finance on the performance of innovative start-ups is factual. All the VC-backed start-ups under study recorded significant improvement in the overall management of the companies, huge increase in the number of employees and steady growth in profitability. As a result of the venture capital investments in start-ups, wealth has been created which has subsequently boosted the macroeconomic wellbeing of the people. The study critically underscores the important link between VC financing of start-ups and poverty reduction. It has equally indicated that venture capital investments in start-ups not only have positive effects on a nation's economic prosperity but also on the social wellbeing of the citizenry. Notwithstanding the present economic and political climate in Nigeria, the study has demonstrated that venture capital investments in innovative start-ups can be worthwhile. The classification of VCs impact in Nigeria in terms of economic and social streams is necessary at this point. While the 
economic impact has been achieved in the start-up companies in form of sales and profitability growth, social impact from venture capital could be seen in the areas of employment opportunities for the teeming population which invariably has improved the standard of living of many Nigerians. The increase in tax revenue collected by the government as a result of growth in profitability and more people gaining employment is beneficial to the entire economy. This revenue could be channelled towards the provision of infrastructure for the citizens. Additionally, the improvement in profitability for VC-backed start-ups will boost international investors' confidence and also adds to investor's profit.

The study reveals that VC investments in start-ups are broad spectrum in approach. Though the provision of funds to start-ups by venture capital companies is an important stage of start-ups life cycle, they do more than that. Other indispensable drivers of this VC-backed start-ups' remarkable performance form a subset of management support. These drivers include: venture capital companies utilize huge part of their resources in understanding new markets and technologies for the investee company; provision of effective coaching for start-ups; augmentation of existing start-up management's range of skills; provision of extensive network of contacts to investee company; ushering in reputation and goodwill to start-up company.

Given that the growth trend has been established in the VC-backed start-ups, it's recommended that the government of Nigeria should not only boost support for start-ups in raising venture capital but also to importantly create an effective enabling environment for venture capital investments.

\section{References}

[1]. Acs, Z., \& Storey, D. (2004). Introduction: Entrepreneurship and economic development. Regional Studies 38: $871-877$

[2]. Akinboyo, G. B. (1987). Job creation as a productivity measure for employment problems in developing countries: The Nigeria and Holland experience. Increasing Productivity in Nigeria, 404-411.

[3]. Anyadike N., Emeh I.E.J \& Ukah F.O (2012). Entrepreneurship development and employment generation in Nigeria: Problems and prospects. Universal Journal of Education and General Studies, 1(4), 088-102.

[4]. ARIYO, D. (2000). The Growth and prospect for Venture Capital activities in Nigeria, Africa Economic Analysis, Retrieved from: http://www.afbis.com/analysis/venture.htm

[5]. AVCA -African Private Equity and Venture Capital Association (2015). Investing in Africa's Small and Growing Businesses: An introduction to private equity in Africa. Retrieved from: http://www.avcaafrica.org/research-publications/african-pe-vc-library/

[6]. Baron, J. N., Burton, M. D., \& Hannan, M. T. (1996). The road taken: Origins and evolution of employment systems in emerging companies. Industrial and Corporate Change, 5(2), 239-275.

[7]. Bhattacherjee, A. (2012). Social science research: Principles, methods, and practices.

[8]. Carree, M. A., \& Thurik, A. R. (2005). The impact of entrepreneurship on economic growth. Handbook of entrepreneurship research, 437-471.

[9]. Caulderwood Kathleen (2015). Sub-Saharan Africa Falls Behind in Fight Against Extreme Poverty: World Bank Report. Retrieved from http://www.ibtimes.com/sub-saharan-africa-falls-behind-fight-against-extremepoverty-world-bank-report-1881460

[10]. Central Bank of Nigeria (2005). Guidelines for the Small and Medium Enterprises Equity Investment Scheme. Abuja, Nigeria.

[11]. Central Bank of Nigeria (2016). Quarterly Economic Reports. Retrieved from: https://www.cbn.gov.ng/out/2016/ccd/cbn\%20economic\%20report\%20second\%20quarter\%202016.pdf

[12]. Cornelius, B. (2005). The institutionalisation of venture capital. Technovation, 25(6), 599-608.

[13]. Cumming, D., Fleming, G., \& Schwienbacher, A. (2008). Financial intermediaries, ownership structure and the provision of venture capital to SMEs: evidence from Japan. Small Business Economics, 31(1), 59-92.

[14]. Daramola, A. (2012). New Technology-Based Firms and Venture Capital Policy in Nigeria. Journal of Innovation Economics \& Management, (1), 163-181.

[15]. Davila, A., Foster, G., \& Gupta, M. (2003). Venture capital financing and the growth of startup firms. Journal of business venturing, 18(6), 689-708.

[16]. Dejardin, M., \& Fritsch, M. (2011). Entrepreneurial dynamics and regional growth. Small Business Economics, 36(4), 377-382. 
[17]. Fritsch, M. (2008). How does new business formation affect regional development? Introduction to the special issue. Small Business Economics, 30(1), 1-14.

[18]. Fritsch, M., \& Mueller, P. (2004). Effects of new business formation on regional development over time. Regional Studies, 38(8), 961-975.

[19]. Fritsch, M., \&Noseleit, F. (2009). Investigating the anatomy of the employment effects of new business formation (No. 2009, 001).Jena economic research papers.

[20]. Gimeno, J., Folta, T. B., Cooper, A. C., \& Woo, C. Y. (1997). Survival of the fittest? Entrepreneurial human capital and the persistence of underperforming firms. Administrative science quarterly, 750-783.

[21]. Goldberg, R. T. (2012). An Introduction to Start-up Financing and a New Approach to Attracting Capital Resources. StartupFactory, LLC. White Paper.

[22]. Gompers, P., \& Lerner, J. (1999). The Venture Capital Cycle (Cambridge, Mass.).

[23]. Hallberg, K. (1998). Small \& Medium Scale Entities. A Framework for Intervention. World Bank Small Enterprises Unit. Private Sector Development. Washington DC.

[24]. Hellmann, T., \& Puri, M. (2000). The interaction between product market and financing strategy: The role of venture capital. Review of Financial studies, 13(4), 959-984.

[25]. Henry, G.T. (1990). Practical Sampling. Newbury Park, CA: Sage.

[26]. Ihugba, O. A., Odii, A., \& Njoku, A. C. (2013). Challenges and prospects of entrepreneurship in Nigeria. Academic Journal of Interdisciplinary Studies, 2 (5), 25.

[27]. Kaplan, S. N., \& Strömberg, P. (2003). Financial contracting theory meets the real world: An empirical analysis of venture capital contracts. The Review of Economic Studies, 70(2), 281-315.

[28]. Kauffmann, C. (2005). Financing SMEs in Africa. Policy Insights No. 7, a joint publication of the African Development Bank and the OECD Development Centre.

[29]. K Geronikolaou, G., \& Papachristou, G. (2012).Venture capital and innovation in Europe. Scientific Research, Modern Economy.

[30]. Koster, S., \& Stel, A. (2014). The relationship between start-ups, market mobility and employment growth: An empirical analysis for Dutch regions. Papers in Regional Science, 93(1), 203-217.

[31]. Kothari, C. R. (2003). Research Methodology-Methods \& Techniques, Wishawa Prakashan, New Delhi. Ali SS, Models in Consumer Buying Behaviour, Deep \& Deep Publications.

[32]. Mani, S., \& Bartzokas, A. (2004). Institutional support for investment in new technologies: the role of venture capital institutions in developing countries. Financial Systems, Corporate Investment in Innovation and Venture Capital, Cheltenham, UK and Northampton, Mass. USA: Edward Elgar, 117-158.

[33]. Merriam, S. B. (1998). Qualitative research and case study applications in education. San Francisco: Jossey-Bass.

[34]. Newman, W. L. (1994). Social research methods. Allys and bacon, Boston, USA.

[35]. Obadan, M. I., \& Odusola, A. F. (2000). Productivity and Unemployment in Nigeria. National Centre for Economics Management and Administration. Ibadan.

[36]. OECD (2012).Innovation for development. OECD Directorate of Science, Technology and Industry, Paris

[37]. Ollor, W. G., \& Dagogo, D. W. (2009). The effect of venture capital financing on the economic value added profile of Nigerian SMEs. African Journal of Accounting, Economics, Finance and Banking Research, $5(5)$.

[38]. Ovat, O. O. (2013). Liquidity Constraints and Entrepreneurial Financing in Nigeria: The Fate of Fresh Graduate Entrepreneurs. Global Journal of Management and Business Research, 13(9).

[39]. Penrose, E. T. 1959. The Theory of the Growth of the Firm. New York, John Wiley.

[40]. Poku, K., \& Frimpong, F. A. (2009). The assessment of the prospects of venture capital finance in Ghana: The views and perception of some selected SMEs in Ghana. In Ninth Annual IBER and TLC Conference Proceedings.

[41]. Raheem, M. I. (1993). Nigeria for Africa: A case for labour export. Applied Economics and Economic Policy-In Honour of Emmanuel C. Edozien, Ibadan University Press, Ibadan.

[42]. Sanusi, J. (2003). Overview of Government's Efforts in the Development of SMEs and the Emergence of SMEEIS. Retrieved from: www.cenbank.org

[43]. Sekaran, U. (2003). Research Methods for Business: A skill building approach. United States of America: John Wiley \& Sons, Inc 
DOI: $10.21522 /$ TIJMG.2015.03.02.Art001

ISSN: $2520-310 \mathrm{X}$

[44]. Soludo, C. C. (2004, July). Consolidating the Nigerian banking industry to meet the development challenges of the 21 st century. In being an address delivered to the Special Meeting of the Bankers Committee, held on July (Vol. 6).

[45]. UNDP (2012). Tackling poverty by growing SMEs - UNDP South Africa. Retrieved from http://www.za.undp.org/content/south_africa/en/home/ourwork/povertyreduction/successstories/tacklingpoverty-by-growing-smes--undp-south-africa/

[46]. Waddell, S. J. (1995). Emerging Social-economic Institutions in the Venture Capital Industry. American Journal of Economics and Sociology, 54(3), 323-338.

[47]. Wennekers, S., \& Thurik, R. (1999). Linking entrepreneurship and economic growth. Small business economics, 13(1), 27-56.

[48]. Westlund, H., \& Olsson, A. (2011). Economic Entrepreneurship, Startups and Their Effects on Local Development: The Case of Sweden. ResearchGate.

[49]. White Paper on International Development. (2000). Eliminating World poverty: Making Globalization Work for the Poor. London: Stationary office. 